\title{
IDENTIFIKASI FAKTOR-FAKTOR PENGHAMBAT PEMBELAJARAN JARAK JAUH (PJJ) DI MUSIM PANDEMI CORONA PADA SISWA SMP
}

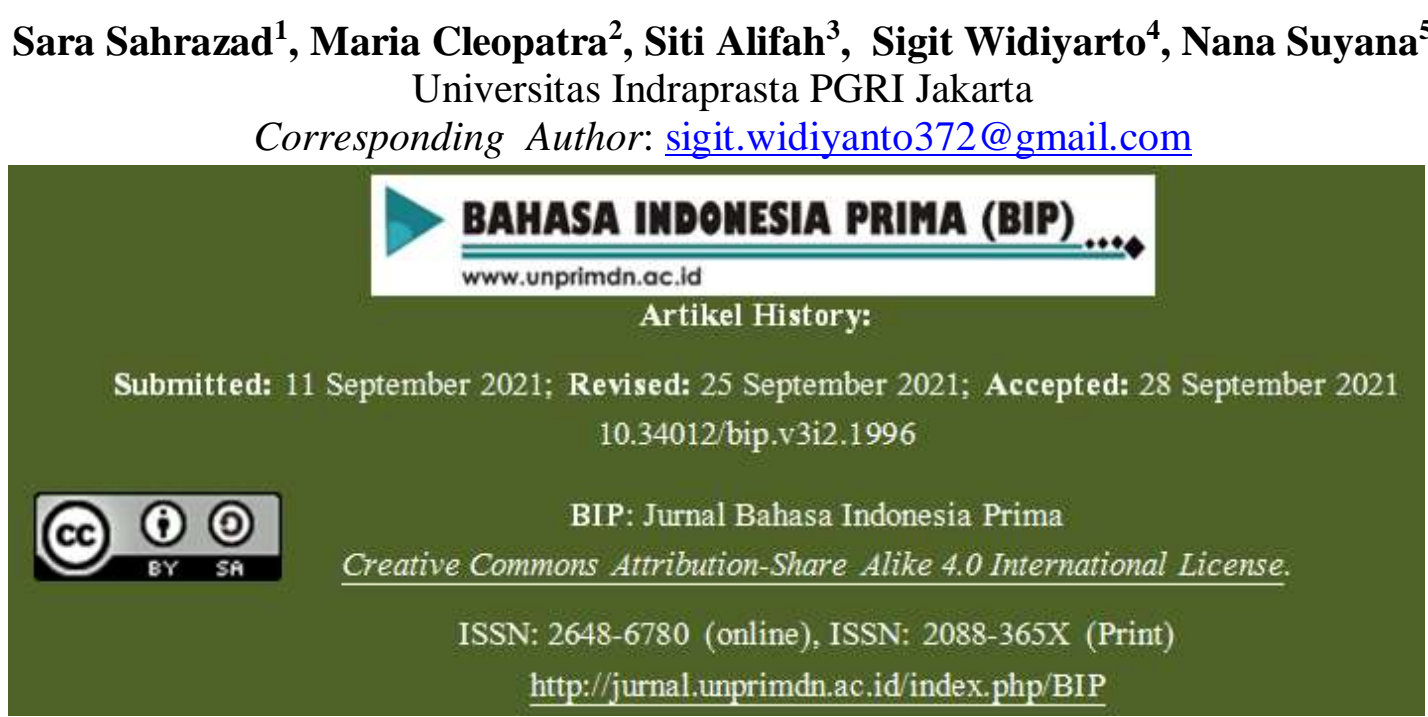

Abstrak-Tujuan penelitian ini adalah, untuk mengetahui faktor-faktor apakah yang menjadi penghambat dalam PJJ siswa, kedua, untuk mengetahui faktor-faktor apakah yang berperan dalam keberhasilan PJJ, dan ketiga untuk mengetahui proses belajar PJJ para siswa SMP Bhakti Candra dan SMP Purwa Bakti Kabupaten Bogor . metode penelitian yang digunakan adalah adalah kualitatif yang berjenis studi kasus. Dalam pengumpulan data digunakan metode observasi peran serta, wawancara mendalam dan dokumentasi . hasil penelitian menunjukkan bahwa Faktor penghambat PJJ yaitu sebagian besar orang tua tidak bisa selalu mendampingi peserta didik dalam belajar karena memiliki pekerjaan yang tidak bisa ditinggalkan. Tugas yang diberikan guru memerlukan penjelasan lebih, dikarenakan orang tua kurang menguasai materi yang diberikan oleh guru, dan motivasi belajar pada peserta didik menjadi menurun. mengupayakan cara untuk mengatasi hambatan PJJ diantaranya yaitu guru dapat menggunakan teknologi untuk melangsungkan proses pembelajaran dengan memanfaatkan kecanggihan teknologi sesuai kebutuhan materi pembelajaran dan mempermudah guru dalam proses pembelajaran

Kata kunci : PJJ, faktor penghambat, pandemi corona

Abstract-The purpose of this study was to find out what factors were the obstacles in student PJJ, second, to find out what factors played a role in the success of PJJ, and third to determine the learning process of PJJ students at Bhakti Candra Middle School and Purwa Bakti Junior High School, Bogor Regency. . The research method used is a qualitative case study type. In collecting data, the method of participation observation, in-depth interviews and documentation was used. The results of the study indicate that the inhibiting factor for PJJ is that most parents cannot always accompany students in learning because they have jobs that cannot be abandoned. The tasks given by the teacher require more explanation, because parents do not master the material given by the teacher, and the learning motivation of students decreases. seek ways to overcome PJJ barriers, including that teachers can use technology to carry out the learning process by utilizing technological sophistication 
according to the needs of learning materials and making it easier for teachers in the learning process

Keywords: PJJ, inhibiting factor, corona pandemic

\section{A. Pendahuluan}

Pembelajaran jarak jauh (PJJ) merupakan alternatif belajar selain pembelajaran tatap muka. Pembelajaran jarak jauh dilakukan setelah timbulnya virus corona 19 dan disusul oleh varian baru seperti varian Delta dan MU yang melanda seantero dunia. Pembnahan dan perubahan pembelajaran cukup menyulitkan semua pihak. Pihak sekolah berupaya untuk dapat menekan jumlah siswa yang terinfeksi, melalui himbauan dan penyuluhan.

Pada awal Maret 2021 pemerintah mencanangkan vaksinasi massal. Hal ini dianggap dapat mengurangi penyebaran yang kian cepat dan ganas. Namun, ada pihak yang belum setuju dengan adanya vaksinasi, terutama kepada para siswa. Oleh karena itu PJJ dianggap metode pembelajaran yang masih dianggap aman dan efesien. Metode belajar dari rumah (BDR) dapat dilaksanakan dengan memperhatikan kebuthan siswa yang beragam.

Pembelajaran dari rumah (BDR) mempunyai 2 macam yaitu Pembelajaran berbasis jaringan (PJJ daring). Dan luring ( PPJ luar jaringan). PJJ daring dapat menggabungkan teknologi informasi dan tekniologi berbasis internet. PJJ luring merupakan pembelajaran jarak jauh yang mengandalkan siaran TV,radio, modul elektronik dan sebagainya.

Pembelajaran tersebut selain menjadi alternatif namun dapat membuat stres bagi siswa karena para siswa duduk berjamjam di depan laptop atau HP, tanpa dapat berinteraksi secara langsung dengan teman-teman dan guru serta tugas-tugas yang diberikan. Dampak stres dapat menimbulkan hal buruk pada output pembelajaran para siswa.. Kondisi siswa yang mengalami stres akademik dijelaskan oleh Oon (2007) bahwa stres akademik yang dialami siswa secara terus menerus akan mengakibatkan penurunan daya tahan tubuh siswa sehingga mudah mengalami sakit. Dalam jangka panjang, stres yang tidak diatasi dapat mempengaruhi mental siswa berupa kelelahan mental dan patah semangat sehingga menyebabkan siswa mengalami masalah perilaku. Selain itu stress yang ditimbulkan dari hasil akademik rendah, ditimbulkan oleh gaya belajar siswa yang tidak sesuai dengan gaya pengajaran guru mereka. Gaya belajar adalah karakteristik dan strategi individu untuk melakukan pendekatan belajar yang tepat dan sesuai dengan kebutuhan dalam belajar (Fleming \& Mills, 1992). Gaya belajar pada setiap individu berbeda, baik pada kecepatan dalam menerima informasi dan cara memproses informasi. Menurut Darmadi (2017) gaya belajar dipengaruhi oleh dua faktor, yaitu faktor internal dan faktor eksternal. Faktor internal terdiri dari faktor jasmaniah, psikologis, dan kelelahan, sedangkan faktor eksternal berasal dari faktor keluarga, sekolah, dan masyarakat. Faktor-faktor tersebut dapat mempengaruhi potensi siswa dalam bidang akademik. Rosalin (2020) mengungkapkan bahwa bahwa $58 \%$ anak memiliki perasaan yang tidak menyenangkan selama menjalani kebijakan belajar daring dan $38 \%$ anak berpendapat bahwa belajar di rumah belum menerapkan program yang 
baik oleh sekolah. Gaya belajar berperan penting agar siswa dapat menerapkannya sehingga tidak menimbulkan kebosanan selama belajar daring.

Berdasarkan uraian diatas maka peneliti dapat memberikan beberapa batasan masalah dalam penelitian ini, pertama, faktor-faktor apakah yang menjadi penghambat dalam PJJ siswa, kedua, faktor-faktor apakah yang berperan dalam keberhasilan PJJ, dan ketiga bagaimana proses belajar PJJ para siswa. Sedangkan tujuan penelitian ini adalah, untuk mengetahui faktor-faktor apakah yang menjadi penghambat dalam PJJ siswa, kedua, untuk mengetahui faktorfaktor apakah yang berperan dalam keberhasilan PJJ, dan ketiga untuk mengetahui proses belajar PJJ para siswa SMP Bhakti Candra dan SMP Purwa Bakti Kabupaten Bogor.

Pemilihan lokasi penelitian, didasarkan kepada, kondisi sekolah yang memerlukan penanganan pada permasalahan PJJ. Disamping itu, atas saran dinas pendidikan setempat. Penelitian diaksanakan pada tanggal 3 September 2017 sampai dengan Desember 2017.

\section{B. Metode Penelitian}

Metode Penelitian dalam penelitian ini adalah kualitatif yang berjenis studi kasus. Dalam pengumpulan data digunakan metode observasi peran serta, wawancara mendalam dan dokumentasi. Sumber data penelitian ini adalah kata-kata dan tindakan dari subjek penelitian yang meliputi Kepala Sekolah, dewan Guru dan Siswa. Penelitian ini menggunakan pendekatan kualitatif deskriptif. Teknik analisis datanya menggunakan model analisis interaktif yang mencakup beberapa komponen yang saling berkaitan, adapun langkah-langkanya dapat dilihat pada bagan 1 dibawah ini.

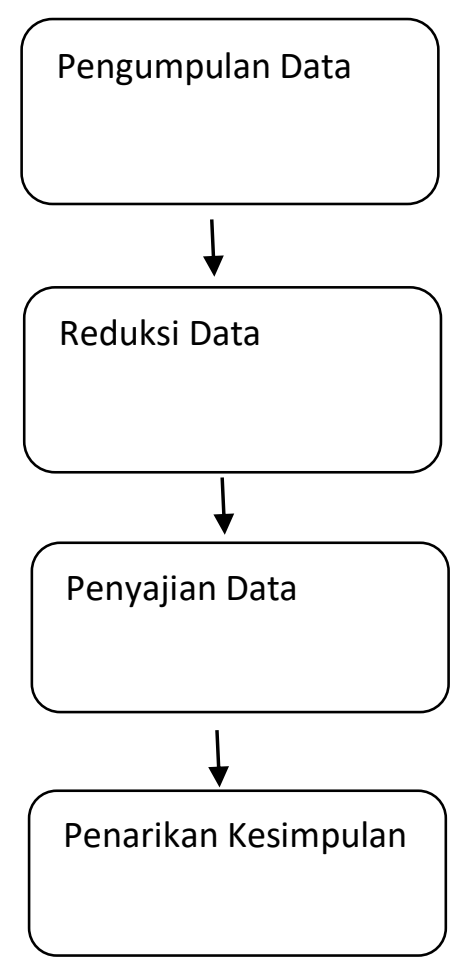

Bagan. 1 Urutan Langkah Penelitian

Pengumpulan data, reduksi data, penyajian data dan penarikan kesimpulan. Untuk pengecekan keabsahan data digunakan perpanjangan penelitian, ketekunan pengamatan, dan triangulasi.

\section{Hasil dan Pembahasan}

Beberapa kendala pada pelaksanaan PJJ adanya beberapa kelemahan diantaranya orang tua masih kesulitan untuk menjadi pengganti guru sebagai fasilitator pada saat pendampingan proses belajar, karena terdapat orang tua yang kurang memahami materi tersebut. Perlu adanya perbaikan lagi agar mencapai hasil yang maksimal. Faktor pendukung yang ditemukan dalam pelaksanaan PJJ di para siswa SMP Bhakti Candra dan SMP Purwa Bakti Kabupaten Bogor yang pertama yaitu guru mempersiapkan perencanaan yang matang dalam melaksanakan PJJ, karena guru berperan penting dalam pelaksanaan PJJ. Faktor 
pendukung yang kedua yaitu dari pihak sekolah memberikan bantuan berupa subsidi kuota internet untuk meringankan beban orang tua, sehingga PJJ dapat dilaksanakan dengan lancar.

Ketiga guru dan orang tua dapat memanfaatkan teknologi dan komunikasi untuk saling berinteraksi tanpa adanya kendala waktu, karena dapat dilakukan kapan saja dan dimana saja. Sependapat dengan Latip (2020: 109) yang menyatakan bahwa faktor penentu keberhasilan PJJ adalah teknologi yang merupakan media, alat dan sarana penunjang terjadinya proses interaksi antara pengajar dan pembelajar. Faktor penghambat pelaksanaan PJJ yang pertama yaitu sebagian orang tua yang memiliki pekerjaan tetap, tidak bisa selalu mendampingi peserta didik dalam kegiatan PJJ, karena memiliki tugas dan tanggung jawab dalam pekerjaannya. Kedua yaitu orang tua memerlukan penjelasan lebih terkait dengan tugas yang diberikan kepada peserta didik. Ketiga yaitu motivasi belajar peserta didik menjadi menurun karena kurang pendampingan dari orang tua, dan tidak belajar secara langsung dengan guru.

Sesuai pernyataan oleh Dewi (2020: 61) yang menyatakan bahwa faktor penghambat pembelajaran jarak jauh diantaranya yaitu pekerjaan orang tua Pihak sekolah melaksanakan upaya-upaya untuk mengatasi hambatan PJJ diantaranya guru dapat menggunakan teknologi untuk melangsungkan proses pembelajaran dengan memanfaatkan kecanggihan teknologi sesuai kebutuhan materi pembelajaran dan mempermudah guru dalam proses pembelajaran. PJJ menggunakan dua cara yaitu pembelajaran daring dan pembelajaran luring. Kedua pembelajaran ini harus diinovasikan oleh guru sehingga proses pelaksanaan PJJ dapat berjalan dengan baik dan sesuai dengan tujuan pembelajaran. Kepala sekolah dan guru juga selalu memberi motivasi agar pelaksanaan PJJ dapat berjalan, dengan itu harus ada dukungan dari orangtua peserta didik.

Rangkuman dari data, berdasarkan wawancara respondent adalah sebagai berikut, wawancara kepada orang tua (ACB), pada kesempatan awal peneliti bertanya, Apakah yang menjadi kendala utama pada proses PJJ ? " awal dari PJJ, masih dapat terkendali, sebab ,kami sebagai orangtua, masih mendapatka kesempatan bekarja dari rumah, namun ketika kami harus bekerja keluar rumah, maka timbulnya beberapa kendala seperti anak tidak faham dengan materi yang diberikan guru, anak merasa kesepian, sebab terbiasa belajar bareng denagna anak lain disekolah" Lain halnya dengan orang tua lain (HF), berpendapat lain, "oleh karena saya sebagai wirausaha UMKM, maka saya dapat mengatur waktu, pada saat anak memerlukan saya, dan waktu untuk bekerja, sebab waktu dapat saya atur sendiri”.

Kepala sekolah berpendapat, bahwa "PJJ, dapat mengurangi jam belajar siswa. Sehingga dapat menurunkan kualitas belajar. Anak harus menyiapkan alat komunikasi dan pulsa. Bag siswa yag kurang mampu memerlukan penyesuaian yang perlu diberikan solusi" Hal ini senada dengan salah satu guru, yang menyatakan, bahwa pembelajaran memerlukan waktu dan adaptasi , namun sapat menurunkan semangat belajar siswa.

\section{Simpulan}

Faktor penghambat PJJ yaitu sebagian besar orang tua tidak bisa selalu mendampingi peserta didik dalam belajar karena memiliki pekerjaan yang tidak bisa 
BIP: Jurnal Bahasa Indonesia Prima Vol. 3, No. 2, 2021, September 2021, PP.

ditinggalkan. Tugas yang diberikan guru memerlukan penjelasan lebih, dikarenakan orang tua kurang menguasai materi yang diberikan oleh guru, dan motivasi belajar pada peserta didik menjadi menurun. Berdasarkan faktor penghambat pihak sekolah mengupayakan cara untuk mengatasi hambatan PJJ diantaranya yaitu guru dapat menggunakan teknologi untuk melangsungkan proses pembelajaran dengan memanfaatkan kecanggihan teknologi sesuai kebutuhan materi pembelajaran dan mempermudah guru dalam proses pembelajaran. PJJ menggunakan dua cara yaitu pembelajaran daring dan pembelajaran luring. Kedua pembelajaran ini harus diinovasikan oleh guru, sehingga proses pelaksanaan PJJ dapat berjalan dengan baik dan sesuai dengan tujuan pembelajaran.

Peneliti mengucapkan terimakasih pada pihak sekolah, yaitu SMP Bakti Chandra dan SMA Purwa Bakti yang mau membantu pada pelaksanaan penelitian ini.

\section{Daftar Pustaka}

Dewi, M. (2020). Analisis Kerja Sama Guru dengan Orang Tua dalam Pembelajaran Online di Era Covid 19 di MI Azizan Palembang. Jurnal Edukasi Madrasah Ibtidaiyah, 2(2), 54-64.

Darmadi. (2017). Pengembangan Model dan Metode Pembelajaran dalam Dinamika Belajar Siswa. Yogyakarta: Deepublish.

Fleming, N. D., \& Mills, C. (1992). Helping Students Understand How They Learn. Madison, Wisconsin, USA: Magma Publications.

Latip, A. (2020). Peran Literasi Teknologi
Informasi dan Komunikasi pada Pembelajaran Jarak Jauh di Masa Pandemi Covid-19. Jurnal Edukasi dan Teknologi Pembelajaran, 1(2), 107-115.

Oon, A. N. L. (2007). Seri Teaching Children Handling Study Stress (diterjemahkan oleh A. K. Anwar). Jakarta: Elex Media Komputindo

Rosalin. (2020). Dampak Covid 19 terhadap Anak. Jakarta: Kementerian PPPA

Wibowo, A. N., Supandi, A., Andri, A., \& Widiyarto, S. (2020). Pemanfaatan Pembelajaran ICT Dalam Optimalisasi Proses Belajar Mengajar Guru SMP. Jurnal Pengabdian UntukMu NegeRI, 4(2), 228-230. 